\title{
PENGARUH KUALITAS AUDIT PADA HUBUNGAN MORALITAS, BUDAYA DAN PELAYANAN FISKUS TERHADAP KEPATUHAN WAJIB PAJAK
}

\author{
Agustine Dwianika ${ }^{1}$ Muhd. Nuryanto Amin ${ }^{2}$ Calista Setiyahadi ${ }^{3}$ \\ Fakultas Humaniora dan Bisnis, Universitas Pembangunan Jaya \\ agustine.dwianika@upj.ac.id \\ Fakultas Ekonomi dan Bisnis, Universitas Trisakti \\ nanotrisakt@gmail.com \\ Fakultas Humaniora dan Bisnis, Universitas Pembangunan Jaya \\ calistasetiahadi.student@upj.ac.id
}

\begin{abstract}
This research aim to examine: (1) The influence of morality on tax compliance (2) The influence of culture on tax compliance.(3)The influence of tax services quality on tax compliance. And (4) The influence of audit quality, morality, tax services quality on tax compliance in Serpong Tax Office and Pondok Aren Tax Office. This study uses a quantitive approach and employs a regression model analysis by using 103 quistionare from respondents. The results of this study found that audit quality, morality, culture and tax services quality simultanesously influenced on tax compliance. Easy to pay and reporting also good and clearly informations are important for taxpayers and ultimately increase tax awareness to make taxpayers compliant and obey about tax provisions. The higher the audit quality stated on the use of Big Four KAP by taxpayers, it can increase the level of taxpayer compliance which is influenced by taxpayer morality, the culture that is understood by taxpayers and the quality of taxpayer services obtained by taxpayers.
\end{abstract}

Keyword: Audit Quality, Morality, Culture, Tax Service and Tax Compliance.

\section{PENDAHULUAN}

Kualitas audit sering juga diartikan segala hal yang mungkin, atau memiliki probabilitas yang dapat terjadi pada saat dilakukannya audit laporan keuangan milik klien, dimana bisa diketemukan pelanggaran yang pada sistem akuntansi klien serta melaporkannya pada laporan keuangan yang akan diaudit. Dan dalam melaksanakan tugasnya tersebut auditor berpedoman pada standar audit di Indonesia, PSAK maupun IFRS (Riadi, 2018). Begitu pentingnya opini audit dalam laporan keuangan untuk para pemangku kepentingan, diantaranya adalah bagi Direktorat Jendral Pajak dalam rangka memastikan kondisi keuangan perusahaan dan sebagai bahan pertimbangan bagi para fiskus dalam proses audit pajak.

Kemampuan audit sesoerang berpengaruh positif pada indikasi adanya kecurangan pada laporan keuangan (Sunardi dan Amin, 2012). Oleh karenanya 
kualitas audit yang didasarkan pada kemampuan auditor menjadi penting untuk meminimalisir risiko salah saji laporan keuangan yang berimbas pada pembayaran kewajiban nya. Namun demikian, tidak serta merta laporan keuangan audit yang baik selalu mencerminkan kepatuhan mereka akan pembayaran kewajiban pajak pada kas negara. Moralitas seorang wajib pajak juga menjadi hal yang penting dalam rangka meningkatkan kepatuhan wajib pajak membantu pendapatan pajak. Wajib pajak yang sadar pajak mengakibatkan akan taat hukum dan aturan pembayaran dan pelaporan pajak sesuai dengan ketentuan perundang-undangan.

Sebagai contohnya, baru-baru ini diperbincangkan kembali adanya tiga pengusaha yang terlibat kasus penggelapan pajak sebesar Rp7.985.500.000 pada sejumlah wilayah kerja Kantor Pelayanan Pajak (KPP) Kota Medan di akhir tahun 2017 lalu. Mereka didakwa melakukan penggelapan pajak pada Januari 2007Januari 2008, dan dituntut oleh Jaksa Penuntut Umum (JPU) Kejaksaan Tinggi Sumatra Utara, Ibu Netty Silaen di Pengadilan Tindak Pidanan Korupsi (Tipikor) kota Medan. Tercatat bahwa Direktur dari PT PWS (Rudi Nasution), Pemilik PT JST (Tiandi Lukman), Direktur PT BIP (Hendra Gunawan) dan Direktur PT ABF (Zulpan) secara bersama-sama menyetorkan pajak atas nama perusahaan mereka ke KPP Kota Medan. Kemudian mereka membayarkan pajak ke KPP Kota Medan dengan jumlah tunggakan pajak yang mencapai sebesar Rp79.585.025.850. Pembayaran tunggakan pajak para pengusaha itu diterima petugas pajak pada KPP Kota Medan. Namun, setelah dilakukan audit oleh petugas pajak dan ditemukan adanya penyimpangan dan menimbulkan kerugian negara senilai Rp7,9 miliar. (www.mediaindonesia.com, 2018).

Disisi lain, Yoga (2016) menuliskan pada portal atau laman Kompas.com tertanggal 27 Oktober 2016 bahwa Direktorat Jenderal (Ditjen) Pajak menyampaikan rasa keprihatinan yang sangat melihat kelakuan perusahaanperusahaan pertambangan di sektor mineral batubara (Minerba) dan minyak-gas (Migas), perusahaan-perusahaan itu diketahui tidak patuh melaporkan Surat Pemberitahuan Tahunan (SPT) kepada Ditjen Pajak. Berdasarkan data tahun 2011 lalu, dari 3.037 Wajib Pajak sektor pertambangan Minerba dan Migas, terdapat 2.900 Wajib Pajak yang tidak melapor Surat Pemberitahuan Tahunan (SPT) dan 
hanya 137 Wajib Pajak yang melapor. Sehingga terhitung hanya 4,5\% (persen) Wajib Pajak sektor pertambangan Minerba dan Migas yang patuh, sedangkan 95,5\% (persen) lainnya tidak patuh melakukan kewajiban pajaknya. Kemudian pada tahun 2015, Wajib Pajak sektor pertambangan Minerba dan Migas yang melapor Surat Pemberitahuan Tahunan (SPT) hanya 2.500 orang dan 3.600 Wajib Pajak lainnya tidak melapor dari jumlah keseluruhan 6.100 Wajib Pajak. Hal tersebut membuktikan bahwa hanya $41 \%$ (persen) Wajib Pajak sektor pertambangan Minerba dan Migas yang patuh, sedangkan 59\% (persen) lainnya tidak patuh.

Dalam tulisan Fiki (2017) pada portal atau laman Bisnis.Liputan6.com tertanggal 20 Februari 2017, Direktur Jenderal Pajak Kementerian Keuangan, Ken Dwijugiasteadi menjelaskan beberapa faktor penyebab masyarakat Indonesia enggan membayar pajak. Faktor pertama dan kedua ialah karena masih ada masyarakat yang tidak percaya dengan undang-undang di bidang perpajakan dan tidak percaya dengan petugas pajak. Faktor ketiga adalah masih ada masyarakat yang ingin coba-coba tidak membayar pajak apabila tidak ketahuan karena masyarakat berpikir bahwa Ditjen Pajak tidak punya akses, terutama ke perbankan. Faktor keempat adalah lantaran membayar pajak belum menjadi budaya di Indonesia. Faktor kelima yakni ada masyarakat yang belum patuh membayar pajak karena alasan pengisian Surat Pemberitahuan (SPT) Tahunan Pajak Penghasilan $(\mathrm{PPh})$ yang dinilai ribet. Padahal di Amerika Serikat (AS), perusahaan yang termasuk dalam 10 sampai 40 besar, harus mengisi Surat Pemberitahuan (SPT) dengan tingkat ketebalan sampai 100 (seratus) lembar. Sementara di Indonesia masyarakat mengisi Surat Pemberitahuan (SPT) paling banyak hanya 8 (delapan) lembar, yaitu pada SPT 1771 untuk Wajib Pajak Badan. Oleh karenanya kualitas layanan Fiskus terutama terkait pemahaman peraturan perpajakan dianggap penting untuk mendukung kepatuhan wajib pajak diantaranya karena faktor kemudahan melakukan pembayaran dan pelaporan pajaknya.

Perumusan masalah dalam penelitian ini dibuat sebagai penjabaran hal-hal yang menjadi permasalahan utama untuk ditemukan jawabannya melalui 
penelitian terkait, yaitu : 1). Bagaimana pengaruh moralitas terhadap kepatuhan dari Wajib Pajak? 2). Bagaimana pengaruh budaya akan kepatuhan dari Wajib Pajak? 3). Bagaimana pengaruh kualitas pelayanan fiskus terhadap kepatuhan darin Wajib Pajak? 4) Bagaimana pengaruh kualitas audit pada hubungan moralitas, budaya dan kualitas pelayanan fiskus terhadap kepatuhan dari Wajib Pajak? Pengujian atas pengaruh dan hubungan dari variabel diatas menjadi tujuan penelitian ini dan diharapkan hasil penelitian ini kemudian dapat berkontribusi untuk menambah khasanah referensi bagi penelitian mendatang terkait kualitas audit, moralitas, budaya, kualitas pelayanan pada kepatuhan Wajib Pajak Badan serta bermanfaat bagi pembuat kebijakan sebagai bahan pertimbangan dan referensi. Terlebih dalam lingkup penelitian pada fiskus Kantor Pelayanan Pajak Pratama yang memiliki wilayah kerja di daerah Kota Tangerang Selatan.

\section{TELAAH LITERATUR DAN PENGEMBANGAN HIPOTESIS}

Teori Agensi (Agency Theory) adalah menjelaskan bahwa terdapat kepentingan yang berbeda antara agen (manajer) dan prinsipal (pemilik) perusahaan yang pada awalnya dikemukakan oleh Ross (1973) dan kemudian eksplorasi secara mendetail pertama kali dilakukan oleh Jansen dan Meckling (1976). Adanya keinginan oleh pemilik perusahaan untuk memastikan tidak adanya manipulasi atau asimetri informasi antara agen dan prinsipal salah satunya mendorong perusahaan melakukan proses audit. Pertimbangan kualitas audit menjadi penting dalam rangka memastikan independensi seorang auditor dalam memberikan opini auditnya. Sedangkan Teori Kepatuhan (Compliance Theory) dianggap menjadi salah satu acuan literatur bagi peneliti karena teori ini menjelaskan tentang kondisi dimana seseorang patuh atau taat pada suatu aturan tertentu. Tahar dan Rachman (2014) menyatakan bahwa kepatuhan pada perpajakan merupakan pertanggungjawaban kepada Tuhan, bagi pemerintah dan rakyat untuk memenuhi semua kegiatan kewajiban perpajakan dan mendapatkan hak perpajakannya. Kedua grand theory tersebut dianggap saling terkait dalam penellitian ini, karena dengan adanya keinginan pemilik melakukan internal kontrol berupa kebutuhan laporan audit dari KAP yang berkualitas, maka akan 
mendorong meningkatnya kepatuhan pajak dari wajib pajak yang diaudit oleh auditor dengan kualitas yang baik, karena KAP tersebut dianggap memberikan saran dan masukan yang benar dan sesuai dengan ketentuan aturan akuntansi maupun perpajakan.

Di sisi lain, Indar Khaerunnisa dan Adi Wiratno (2014) membuktikan bahwa ada kaitan antara moralitas pajak terhadap kepatuhan Wajib Pajak. Putu Arika Indriyani dan I Made Sukartha (2014) terdapat pengaruh positif antara variabel tanggung jawab moral terhadap kepatuhan pelaporan Wajib Pajak Badan atas penelitian di KPP Pratama Badung Utara. Penelitian Pranata dan Setiawan (2015) memberikan bukti bahwa kewajiban moral berpengaruh positif pada kepatuhan Wajib Pajak dalam rangka melaksanakan kewajibannya membayar pajak restoran ke Dinas Pendapatan Kota Denpasar, Bali. Dicka Christha Koes Febrinda (2016) menyatakan bahwa ada pengaruh yang signifikan antara kewajiban moral dengan kepatuhan Wajib Pajak. Akan tetapi, penelitian Luqman Yusuf Ramadhan (2017) memberikan hasil bahwa moralitas secara parsial tidak mempengaruhi kepatuhan pajak. Hal tersebut memiliki arti bahwa semakin tinggi tingkat moralitas seorang Wajib Pajak, maka tidak selalu mempengaruhi tinggi atau rendahnya kepatuhan pajak Wajib Pajak tersebut. Oleh karenanya peneliti mengajukan hipotesis berikut:

$\mathrm{H}_{1}$ : Moralitas berpengaruh terhadap kepatuhan Wajib Pajak.

Penelitian Luqman Yusuf Ramadhan (2017) memberikan hasil bahwa budaya secara parsial tidak mempengaruhi kepatuhan pajak. Hal tersebut memiliki arti bahwa semakin tinggi tingkat budaya seorang Wajib Pajak, maka tidak selalu mempengaruhi tinggi atau rendahnya kepatuhan dari pajak Wajib Pajak tersebut. Namun, Indar Khaerunnisa dan Adi Wiratno (2014) memberikan hasil bahwa ada pengaruh antara budaya pajak terhadap kepatuhan Wajib Pajak. Selain itu, penelitian yang dilakukan oleh Prasetyo Rudy Adi Mintarto, Hamidah Nayati Utami dan Fransisca Yaningwati (2015) dengan judul "Pengaruh Karakteristik Individu Budaya dan Lingkungan Sosial Terhadap Kepatuhan Pemenuhan Kewajiban Perpajakan (Studi Pada Wajib Pajak Orang Pribadi di Kantor Pelayanan Pajak Pratama Malang Utara)" menghasilkan pernyataan bahwa 
berdasarkan hasil uji $\mathrm{t}$ dan analisis regresi, secara parsial variabel budaya berpengaruh terhadap kepatuhan pemenuhan kewajiban perpajakan. Namun, pengaruh yang dihasilkan tidak signifikan terhadap kepatuhan pemenuhan kewajiban perpajakan, sehingga peneliti mengajukan hipotesis berikut:

$\mathrm{H}_{2}$ : Budaya berpengaruh positif terhadap tingkat kepatuhan Wajib Pajak.

Rohmawati dan Rasmini (2012) menyatakan kualitas pelayanan secara parsial dan simultan bersama variabel lain berpengaruh pada kepatuhan dari Wajib Pajak Orang Pribadi di KPP Pratama Denpasar Barat. Selain itu, penelitian yang dilakukan oleh Cindy dan Mangoting (2013) menghasilkan pernyataan bahwa kualitas akan pelayanan fiskus memiliki pengaruh yang signifikan terhadap kepatuhan dari Wajib Pajak Orang Pribadi di Surabaya. Febrinda (2016) menyatakan bahwa terdapat pengaruh yang signifikan antara kualitas atas pelayanan pajak dengan kepatuhan dari Wajib Pajak.

Sementara Putu Arika Indriyani dan I Made Sukartha (2014) menyatakan bahwa ada pengaruh positif antara variabel kualitas atas pelayanan dengan kepatuhan pelaporan Wajib Pajak Badan di KPP Pratama Badung Utara, Bali. Pranata dan Setiawan (2015) menyatakan bahwa kualitas dari pelayanan berpengaruh positif terhadap kepatuhan dari Wajib Pajak dalam hal membayar kewajiban pajak restoran di Dinas Pendapatan Kota Denpasar, Bali. Oleh karenanya peneliti mengajukan hipotesis penelitian ketiga seperti berikut ini:

$\mathrm{H}_{3}$ : Kualitas dari pelayanan fiskus berpengaruh positif terhadap kepatuhan dari Wajib Pajak.

Kualitas audit secara implisit menekan Perilaku Penghindaran Pajak dalam kaitanya pada isu kepatuhan Wajib Pajak (Martani, 2018). Semakin baik kualitas laporan keuangan yang diaudit akan semakin relevan dengan kondisi keuangan perusahaan yang sebenarnya, demikian pula sebaliknya. Peneliti menyimpulkannya dalam hipotesis berikut:

$\mathrm{H}_{4}$ : Kualitas audit berpengaruh pada hubungan moralitas, budaya serta kualitas atas pelayanan fiskus terhadap kepatuhan dari Wajib Pajak. 


\section{METODE PENELITIAN DAN PEMBAHASAN}

Populasi penelitian ini yaitu seluruh Wajib Pajak yang terdaftar pada Kantor Pelayanan Pajak Pratama di wilayah kerja Tangerang Selatan. Adapun daftar Kantor Pelayanan Pajak Pratama yang termasuk ke dalam wilayah kerja di daerah Kota Tangerang Selatan ialah sebagai berikut:

\section{Tabel 1}

\section{Daftar KPP Pratama di Tangerang Selatan}

\begin{tabular}{|c|l|c|}
\hline No. & \multicolumn{1}{|c|}{ Nama KPP Pratama } & Kode \\
\hline 1 & KPP Pratama Serpong & 411 \\
\hline 2 & KPP Pratama Pondok Aren & 453 \\
\hline
\end{tabular}

Berdasarkan penjelasan sebelumnya, terlihat ada banyak faktor yang mempengaruhi kepatuhan dari Wajib Pajak. Diantaranya peneliti memfokuskan pembahasan pada kualitas audit, moralitas, budaya dan kualitas pelayanan fiskus. Penjabaran dan pemisahan variabel-variabel yang ada di dalam penelitian ini dan skema atau model analisis yang diajukan dapat digambarkan sebagai kerangka pemikiran teoritis dalam penelitian sebagai berikut:

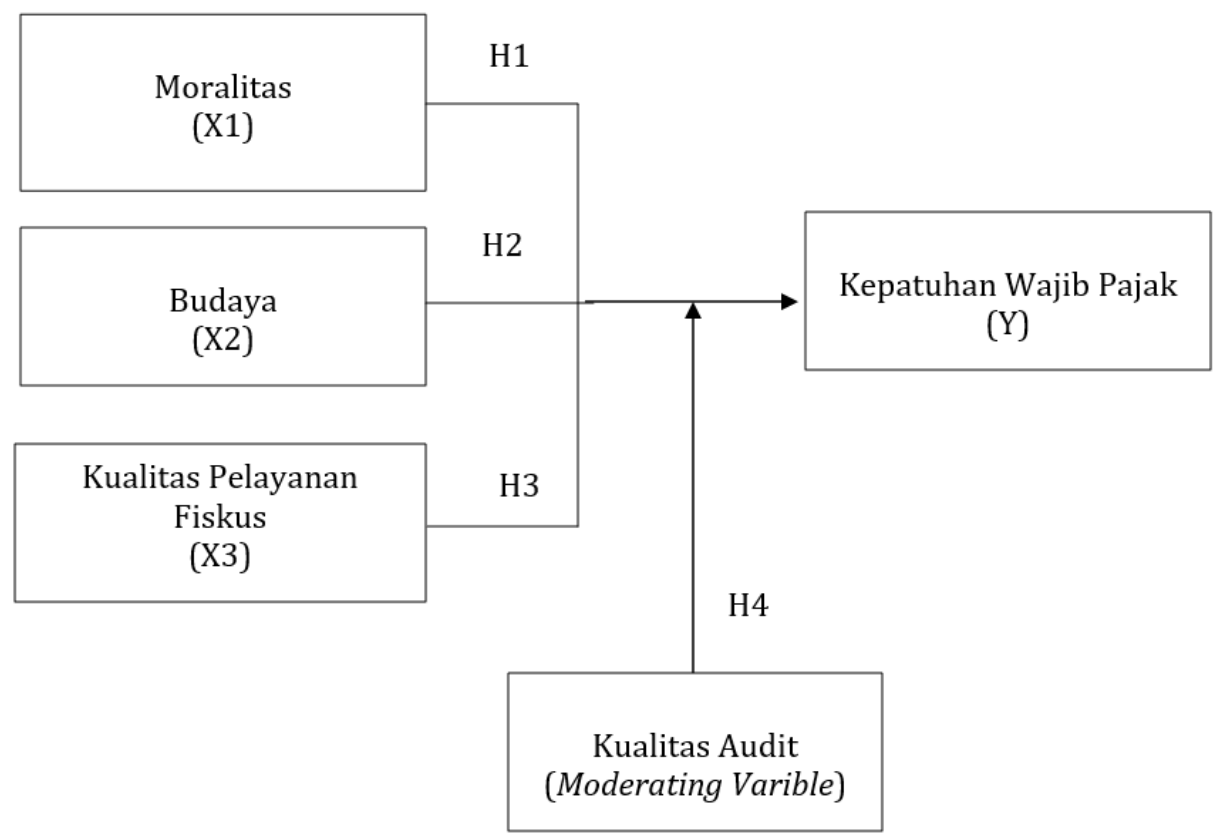

Gambar 2.

Kerangka Pemikiran 
Dari keseluruhan Wajib di kedua Kantor Pelayanan Pajak Pratama di Tangerang Selatan tersebut, kemudian dipilih lagi untuk dijadikan sebagai sampel penelitian. Menurut Sugiyono (2013), yang dimaksud dengan sebagai bagian jumlah serta karakteristik dari suatu populasi, yaitu sampel. Berdasarkan rumus slovin yang dikemukakan Husein (2008), penelitian ini paling tidak diharapkan memiliki 99 sampel. Peneliti menyebarkan kuisioner sebanyak 120 dan kembali pada peneliti sebanyak 103, yaitu dari KPP Serpong sebanyak 53 dan KPP Pondok Aren sebanyak 50.

Data yang telah dikumpulkan akan diolah dan dianalisis dengan cara regresi berganda. Analisis ini digunakan pada setiap sampel di Kantor Pelayanan Pajak Pratama Serpong maupun Kantor Pelayanan Pajak Pratama Pondok Aren dalam rangka mengetahui bagaimana pengaruh dan hubungan variabel independen dengan dependen dalam penelitian. Program SPSS (Software Program Service Solution) digunakan oleh peneliti untuk menganalisa data penelitian yang didapatkan. Dan Analisis data penelitian ini, yaitu menggunakan salah satu jenis analisis data, yakni analisis statistik yang meliputi uji normalitas, uji Multikolinearitas, uji Heteroskedastisitas, Autokorelasi, Uji Validitas dan Realibilitas serta analisis regresi analisis berganda.

Formulasi persamaan regresi linier berganda untuk penelitian ini adalah sebagai berikut

$$
Y=\beta+b_{1} X_{1}+b_{2} X_{2}+b_{3} X_{3}+b_{4} X_{4}+€
$$

\section{Keterangan:}

$\begin{array}{lll}\mathrm{Y} & = & \text { Kepatuhan dari Wajib Pajak } \\ \beta & = & \text { Konstanta } \\ \mathrm{b}_{1}, \mathrm{~b}_{2}, \mathrm{~b}_{3}, \mathrm{~b}_{4} & = & \text { Koefisien masing-masing variabel independen } \\ \mathrm{X}_{1} & = & \text { Moralitas } \\ \mathrm{X}_{2} & = & \text { Budaya } \\ \mathrm{X}_{3} & = & \text { Kualitas pelayanan fiskus } \\ \mathrm{X} 4 & = & \text { Kualitas Audit } \\ € & = & \text { Variabel pengganggu/error }\end{array}$


Untuk mempermudah memahami variabel yang digunakan, peneliti merangkum operasionalisasi variabel penelitian seperti berikut:

Tabel 3.

Operasionalisasi Variabel

\begin{tabular}{|c|c|c|}
\hline Variabel & Indikator & Skala \\
\hline $\begin{array}{l}\text { Moralitas }\left(\mathrm{X}_{1}\right) \\
\text { Independen }\end{array}$ & $\begin{array}{l}\text { 1. Partisipasi warga negara } \\
\text { 2. Sistem perpajakan yang diterapkan } \\
\text { 3. Kebanggaan nasional } \\
\text { 4. Kepercayaan pada pemerintah } \\
\text { Sumber: Widi Widodo }(2010)\end{array}$ & Ordinal \\
\hline $\begin{array}{l}\text { Budaya }\left(\mathrm{X}_{2}\right) \\
\text { Independen }\end{array}$ & $\begin{array}{l}\text { 1. Hubungan antara Aparatur Pajak dengan Wajib Pajak } \\
\text { 2. Peraturan perpajakan yang berlaku } \\
\text { 3. Budaya nasional } \\
\text { Sumber: Widi Widodo (2010) }\end{array}$ & Ordinal \\
\hline $\begin{array}{l}\text { Kualitas Pelayanan } \\
\text { Fiskus }\left(\mathrm{X}_{3}\right) \\
\text { Independen }\end{array}$ & $\begin{array}{c}\text { 1. } \text { Reliability (andal atau wajar) } \\
\text { 2. } \text { Credibility (dapat dipercaya) } \\
\text { 3. Responsiveness (tanggap) } \\
\text { 4. Courtesy (ramah) } \\
\text { 5. Communication (komunikasi) } \\
\text { Sumber: Valarie A. Zeithaml, dkk (2009) }\end{array}$ & Ordinal \\
\hline $\begin{array}{c}\text { Kualitas Audit } \\
\text { Moderating Variabel }\end{array}$ & $\begin{array}{l}\text { Jika diaudit oleh KAP Big Four maka 1, jika bukan Big } \\
\text { Four maka } 0 \text {. } \\
\text { KAP yang berafiliasi dengan big four dianggap memiliki } \\
\text { kualitas pengauditan lebih baik dibandingkan KAP yang } \\
\text { berafiliasi dengan nonbig four. Kualitas tersebut dapat } \\
\text { dilihat dari faktor kemampuan, independensi, dan } \\
\text { pengetahuan auditor dari tiap jenis KAP. Diharapkan } \\
\text { dengan adanya kualitas audit yang lebih baik dapat } \\
\text { memitigasi adanya hubungan perencanaan pajak (Purwanto, } \\
\text { 2012). }\end{array}$ & Dummy \\
\hline $\begin{array}{l}\text { Kepatuhan Wajib } \\
\text { Pajak (Y) } \\
\text { Dependen }\end{array}$ & $\begin{array}{l}\text { 1. Pendaftaran diri untuk memiliki NPWP } \\
\text { 2. Konsistensi Wajib Pajak dalam menyetorkan kembali } \\
\text { SPT } \\
\text { 3. Pembayaran pajak yang terutang sebelum berakhirnya } \\
\text { masa pembayaran pajak } \\
\text { 4. Pelaporan SPT sebelum berakhirnya masa pelaporan } \\
\text { pajak } \\
\text { 5. Pembayaran tunggakan atau tagihan pajak } \\
\text { Sumber: Nasucha dalam Rahayu (2010) }\end{array}$ & Ordinal \\
\hline
\end{tabular}




\section{HASIL PENELITIAN DAN PEMBAHASAN}

Penelitian ini mendapatkan data sebanyak 103 data dari fiskus pada KPP Serpong dan Pondok Aren. Dari pengujian validitas yang dilakukan peneliti, terlihat bahwa korelasi antar masing-masing skor butir pertanyaan terhadap total skor memperlihatkan hasil signifikan, yaitu 0,31. Sehingga dapat dikatakan bahwa setiap pertanyaan adalah valid. Sedangkan hasil uji reliabilitas, menunjukkan bahwa nilai cronbach alpha setiap instrument pertanyaan menunjukkan nilai lebih besar dari 0,60. Yang artinya adalah data yang dikumpulkan dianggap reliabel dengan istrument yang diajukan, kemudian peneliti melakukan pengujian normalitas pada nilai residual dari model regresi yang dibuat. Peneliti menemukan bahwa hasil yang dilihat apakah probability plot memperlihatkan hasil normal, kemudian diperkuat dengan hasil uji Kolmogorov Smirnov yang bernilai sebesar $>0,05(\alpha=5 \%)$, sehingga dapat disimpulkan bahwa residual model regresi tersebut berdistribusi normal.

Hasil uji Heteroskedastisitas memperlihatkan bahwa ada perbedaan dari varians antar residual pengamatan satu dengan pengamatan yang lainnya. Bahwa dianggap regresi yang baik adalah regresi yang didalamnya tidak menunjukkan gejala heteroskedastisitas, sehingga peneliti mendeteksi keberadaan heteroskedastisitas dengan scatterplot. Hasil uji korelasi dengan rank spearman pada variabel bebas dengan nilai residual yang menunjukkan nilai signifikansi > $0,05(\alpha=5 \%)$, maka dapat dikatakan tidak ada heteroskedastisitas dalam model regresi yang diajukan. Hasil Uji Multikolinieritas memperlihatkan korelasi atau hubungan kuat antar variabel bebas dalam model regresi. Dikatakan baik jika regresi yang dibuat seyogyanya tidak ada gejala multikolinieritas didalamnya. Pendeteksian ada tidaknya multikolinieritas dilakukan dengan melihat nilai tolerance dan nilai VIF. Apabila nilainya $>0,10$ dan nilai $\mathrm{VIF}<10$, maka model regresi dikatakan bebas dari multikolinieritas, penelitian ini membuktikan bahwa tidak terdapat multikolinieritas. Model persamaan regresi adalah berikut:

$$
Y=0,625+0,303 X 1+0,314 X 2+0,127 X 3+0,168 X 4
$$


Persamaan regresi linear berganda diatas mengasumsikan bahwa ketika Koefisien atas regresi dari variabel $\mathrm{X} 1, \mathrm{X} 2, \mathrm{X} 3$, dan X4 memperlihatkan tanda positif, yaitu apabila X1, X2, X3, dan X4 mengalami peningkatan maka akan meningkatkan kepatuhan dari Wajib Pajak di Tangerang. Adjusted R2 penelitian ini memperlihatkan nilai 79,8\% artinya 79,8 \% kepatuhan dari Wajib Pajak dalam sampel dapat dijelaskan dari variabel yang diteliti, dan sisanya dijelaskan oleh hal-hal lain diluar penelitian ini. Hasil uji F menunjukkan hasil 35,257 dengan signifikansi 0,000 artinya model regresi dapat digunakan untuk memprediksi kepatuhan dari Wajib Pajak pada sampel atau dianggap variabel yang digunakan dalam penelitian ini secara bersamaan berpengaruh terhadap kepatuhan Wajib Pajak yang diteliti.

Pengujian hipotesis dengan uji t, dilakukan peneliti untuk menguji hipotesis antara satu variabel independen dengan variabel dependen. Tingkat signifikansi yang diacu pada penelitian ini yaitu 0,05. Dan menurut hasil pengujian pada hipotesis yang diajukan oleh peneliti, dapat disimpulkan bahwa Hipotesis pertama yang diajukan yaitu Moralitas berpengaruh terhadap kepatuhan dari Wajib Pajak, menghasilkan signifikansi sebesar 0,000 atau kurang dari 0,05, sehingga dikatakan $\mathrm{H} 0$ ditolak. Berdasarkan hasil ini dapat disimpulkan bahwa kesadaran Moralitas Wajib Pajak berpengaruh signifikan terhadap kepatuhan dari Wajib Pajak. Hipotesis kedua adalah bahwa Budaya berpengaruh terhadap kepatuhan Wajib Pajak, memperlihatkan hasil signifikansi 0,001 positif terhadap kepatuhan Wajib Pajak, artinya Budaya yang diadopsi oleh Wajib Pajak berpengaruh signifikan terhadap kepatuhan Wajib Pajak.

Hipotesis ketiga, adalah bahwa kualitas pelayanan fiskus berpengaruh positif terhadap kepatuhan Wajib Pajak. Dengan hasil uji hipotesis yang menunjukkan nilai sebesar 0,000 dapat diartikan bahwa kualitas pelayanan fiskus berpengaruh signifikan terhadap kepatuhan Wajib Pajak, dan H0 ditolak. Hipotesis 4, adalah bahwa Kualitas audit berpengaruh pada hubungan moralitas, budaya dan kualitas pelayanan fiskus terhadap kepatuhan Wajib Pajak. Hasil uji hipotesis menunjukkan nilai sebesar 0,03 yang mengindikasikan bahwa kualitas 
audit memiliki pengaruh terhadap hubungan antara moralitas, budaya dan kualitas pelayanan fiskus terhadap kepatuhan wajib pajak, dan H0 ditolak.

\section{KESIMPULAN}

Peneliti mempertimbangkan bukti-bukti empiris yang didapatkan dan menyimpulkan bahwa Kesadaran atau Moralitas Wajib Pajak yang berpengaruh signifikan terhadap kepatuhan Wajib Pajak. Seorang wajib pajak yang memiliki kesadaran tinggi akan cenderung untuk mematuhi peraturan hukum ataupun perpajakan yang berlaku. Dengan adanya kesadaran dan kepatuhan yang tinggi dapat meningkatkan pendapatan pajak pemerintah sehingga target APBN dapat terpenuhi dari pendapatan pajak (pajak.co.id, diakses 14 Oktober 2018). Budaya yang dipahami oleh wajib pajak menjadi hal yang penting dalam mendorong kenaikan kepatuhan wajib pajak dalam negri. Budaya sadar pajak yang diharapkan dapat menciptakan wajib pajak yang patuh dan mengikuti peraturan perpajakan yang berlaku menjadi pendorong terciptanya terpenuhinya target pajak nasional.

Kemudahan pembayaran dan pelaporan serta komunikasi dan penyampaian informasi yang jelas menjadi hal yang penting untuk wajib pajak dan pada akhirnya meningkatkan kesadaran pajak menjadikan wajib pajak patuh dan taat ketentuan pajak. Secara bersama-sama kualitas audit berpengaruh pada hubungan moralitas, budaya dan kualitas pelayanan fiskus terhadap kepatuhan Wajib Pajak. Semakin tinggi kualitas audit yang dinyatakan pada penggunaan KAP Big Four oleh wajib pajak, maka dapat menaikkan tingkat kepatuhan wajib pajak yang dipengaruhi oleh moralitas wajib pajak, budaya yang dipahami wajib pajak dan kualitas pelayanan fiskus yang didapatkan oleh wajib pajak.

Keterkaitan teori agensi dan teori kepatuhan dinyatakan selaras dengan hasil penelitian ini. Dengan adanya keinginan bagi pemilik perushaan untuk melakukan intenal kontrol yang sesuai dengan aturan dalam rangka mengurangi kesalahan pelaporan baik akuntansi maupun perpajakan, dapat mendorong kepatuhan wajib pajak untuk melaporkan dan membayaran kewajiban perpajakan serta mendapatkan hak perpajakannya sesuai dengan aturan perundang-undangan yang berlaku di Indonesia. Saran bagi penelitian selanjutnya dapat ditambahkan 
variabel lain yang dinilai dapat lebih mempengaruhi kepatuhan wajib pajak seperti adanya fasilitas $e$-tax, adanya sosialisasi aturan perpajakan secara intensif, dan besar kecilnya kantor pajak bisa dijadikan pertimbangan untuk memberikan kontribusi dalam literasi yang lebih baru dan bermanfaat secara lebih luas.

\section{REFERENSI}

Antara. 2017. Kasus Penggelapan Pajak Miliaran Rupiah di Medan Mulai Disidangkan. http://mediaindonesia.com/read/detail/122136-kasus-pengge lapan-pajak-miliaran-rupiah-di-medan-mulai-disidangkan.

Diakses 9 Oktober 2018.

Arikunto, Suharsimi. 2010. Prosedur Penelitian, Suatu Pendekatan Praktek. PT. Rineka Cipta, Jakarta: Indonesia.

Ariyanti, Fiki. 2017. Kenapa Masyarakat RI Masih Ogah Bayar Pajak?. Diunduh pada 3 Maret 2018 darihttp://bisnis.liputan6.com/read/ 2863036/kenapamasyarakat-ri-masih-ogah-bayar-pajak. Badan”. E-Jurnal Akuntansi Universitas Udayana Vol. 14.1 Januari 2016: 79-90. Bali: Universitas Udayana.

Bertens, K. 2011. Etika. Gramedia Pustaka Utama, Jakarta: Indonesia.

Chaplin, J.P. 2014. Kamus Lengkap Sosiologi. Rajawali Press (Raja Grafindo Persada), Jakarta: Indonesia.

Direktorat Jenderal Pajak. Inklusi Kesadaran Pajak dalam Pendidikan. (online).

Direktorat Jenderal Pajak. Tingkatkan Pelayanan DJP Mekarkan KPP Samarinda.

Eni. 2016. Budaya Indonesia Tidak Malu Kalau Tidak Bayar Pajak. Diunduh pada 3 Maret 2018 dari https://palapanews.com/2016/04/22/budayaindonesia-tidak-malu-kalau-tidak-bayar-pajak/.

Febrinda, Dicka Christha Koes. 2016. Pengaruh Kewajiban Moral, Kualitas Pelayanan, Pemeriksaan Pajak dan Sanksi Perpajakan Pada Kepatuhan Wajib Pajak Pribadi di KPP Pratama Jepara. Universitas Dian Nuswantoro Semarang, Semarang: Indonesia. 
Fiki. 2017. Penyebab Masyarakat Indonesia Enggan Membayar Pajak http://bisnisliputan6.com/read/bisnis/perpajakanindonesia. Diakses pada 10 Oktober 2018.

Ghozali, Imam. 2009. Aplikasi Analisis Multivariate dengan Program SPSS. Badan Universitas Diponegoro, Semarang: Indonesia.

Ho, Daniel. 2009. A Study of Hongkong Tax Compliance Ethics. Internasional Business Research Vol. 2 No. 4, Kowloon Tong: Hong Kong. http://www.pajak.go.id/tingkatkan-pelayanan-djp-mekarkan-kpp-pratamabalikpapan-dan-kpp-pratama-samarinda. Diakses 01 Oktober 2018.

Hurlock, Elizabeth B. 2013. Perkembangan Anak Jilid 1 Edisi Keenam. Erlangga, Jakarta: Indonesia.

Indriyani, Putu Arika dan I Made Sukartha. 2014. Tanggungjawab Moral, Kesadaran Wajib Pajak, Sanksi Perpajakan dan Kualitas Pelayanan Pada Kepatuhan Pelaporan Wajib Pajak Badan. E-Jurnal Akuntansi Universitas Udayana Vol. 7 No. 2, Denpasar: Indonesia.

Jensen \& Meckling. 1976. The Theory of The Firm: Manajerial Behaviour, Agency Cost, and Ownership Structure, Journal of Financial and Economics, 3:305-360.

Jotopurnomo, Cindy dan Yenni Mangoting. 2013. Pengaruh Kesadaran Wajib Pajak, Kualitas Pelayanan Fiskus, Sanksi Perpajakan, Lingkungan Wajib Pajak Berada terhadap Kepatuhan Wajib Pajak Orang Pribadi di Surabaya. Universitas Kristen Petra, Surabaya: Indonesia.

Julianto, Pramdia Arhando. 2017. Ditjen Pajak: Kepatuhan Bayar Pajak Masyarakat Indonesia Masih Rendah. Diunduh pada 17 Februari 2018 dari http://ekonomi.kompas.com/read/2017/07/19/193000326/ditjen-pajakkepatuhan-bayar-pajak-masyarakat-indonesia-masih-rendah.

Khaerunnisa, Indar dan Adi Wiratno. 2014. Pengaruh Moralitas Pajak, Budaya Pajak dan Good Governance Terhadap Kepatuhan Wajib Pajak. Jurnal Riset Akuntansi dan Perpajakan (JRAP), Jakarta: Indonesia.

Kundalini, Pertiwi. 2016. Pengaruh Kesadaran Wajib Pajak dan Pelayanan 
Longdong, Natalia Angelina. 2015. Pengaruh Penyuluhan Perpajakan terhadap Tingkat Kesadaran Wajib Pajak Pada Kantor Pelayanan Pajak Pratama Manado. Manado: Faculty of Economics and Bussiness, Accounting Department Sam Ratulangi University.

Mardiasmo. 2016. Perpajakan-Edisi Terbaru 2016. Yogyakarta: ANDI.

Margono. 2010. Metodologi Penelitian Pendidikan. Rineka Cipta, Jakarta: Indonesia.

Martani, Dwi. 2018. Perpajakan. http://dwimartani.com/perpajakan/. Diakses 2 Oktober 2018.

Menteri Keuangan Republik Indonesia. 2000. Keputusan Menteri Keuangan Republik Indonesia No.544/KMK.04/2000 tentang Kriteria Wajib Pajak yang Dapat Diberikan Pengembalian Pendahuluan Kelebihan Pembayaran Pajak. Jakarta: Indonesia.

Mintarto, Prasetyo Rudy Adi, dkk. 2015. Pengaruh Karakteristik Individu Budaya dan Lingkungan Sosial Terhadap Kepatuhan Pemenuhan Kewajiban Perpajakan (Studi Pada Wajib Pajak Orang Pribadi di Kantor Pelayanan Pajak Pratama Malang Utara). Jurnal Mahasiswa Perpajakan Vol. 5 No. 1, Malang: Indonesia.

Narimawati, Umi. 2008. Metodologi Penelitian Kualitatif dan Kuantitatif, Teori dan Aplikasi. Agung Media, Bandung: Indonesia.

Nazir, Mohammad. 2014. Metode Penelitian. Ghalia Indonesia, Jakarta: Indonesia.

Pegawai Pajak terhadap Kesadaran Wajib Pajak, Jurnal Profita Edisi 3

Perpajakan dan Pelayanan Fiskus terhadap Penerimaan Pajak Penghasilan

Pranata, Putu Aditya dan Putu Ery Setiawan. 2015. Pengaruh Sanksi Perpajakan, Kualitas Pelayanan dan Kewajiban Moral Pada Kepatuhan Wajib Pajak. E-Jurnal Akuntansi Universitas Udayana Vol. 10 No. 2, Denpasar: Indonesia.

Putriani, Ida Ayu Nyoman dan Budiartha, I Ketut. 2016. "Pengaruh Penyuluhan Rahayu, Siti Kurnia. 2010. Perpajakan Indonesia : Konsep dan Aspek Formal. Graha Ilmu, Yogyakarta: Indonesia. 
Ramadhan, Luqman Yusuf. 2017. Pengaruh Kesadaran, Moralitas dan Budaya Pajak Terhadap Kepatuhan Pajak (Studi Pada UKM Siola Kota Surabaya). Universitas Negeri Surabaya, Surabaya: Indonesia.

Riandi, Muchlisin.2018. Pengertian, Indikator dan Pengukuran Kualitas Audit.

Kajian Pustaka. Jakarta.

Robbins, Stephen P. dan Mary Coulter. 2012. Management. Pearson Education, Inc., New Jersey: United States.

Rochaety, Ety, dkk. 2009. Metodologi Penelitian Bisnis. Mitra Wacana Media, Jakarta: Indonesia.

Rohmawati, Alifa Nur dan Ni Ketut Rasmini. 2012. Pengaruh Kesadaran, Penyuluhan, Pelayanan dan Sanksi Perpajakan pada Kepatuhan Wajib Pajak Orang Pribadi. E-Jurnal Akuntansi Universitas Udayana Vol. 1 No. 2, Denpasar: Indonesia.

Santosa, Pandji. 2008. Administrasi Publik: Teori dan Aplikasi Good Governance. PT. Refika Aditama, Bandung: Indonesia.

Setiawan, Sakina Rakhma Diah. 2013. Tingkat Kepatuhan Pajak Pelaku Usaha Kecil Paling Rendah. Diunduh pada 17 Februari 2018 dari http://ekonomi.kompas.com/read/2013/11/21/1605321/Tingkat.Kepatuhan. Pajak.Pelaku.Usaha.Kecil.Paling.Rendah.

Singarimbun, Masri dan Sofian Effendi. 2015. Metode Penelitian Survei. LP3ES, Jakarta: Indonesia.

Sugiyono dan Susanto, Agus. 2015. Cara Mudah Belajar SPSS \& Lisrel Teori dan Aplikasi untuk Analisis Data Penelitian. Bandung: Alfabeta.

Sugiyono. (2013). Metode Penelitian Kuantitatif, Kualitatif dan R\&D. Alfabeta, Bandung: Indonesia.

Sujarweni, V. Wiratna. 2016. Kupas Tuntas Penelitian Akuntansi dengan SPSS.

Sukmadinata, Nana S. 2013. Metode Penelitian Pendidikan. PT. Remaja Rosdakarya, Bandung: Indonesia.

Sukmana, Yoga. 2016. Kepatuhan Pajak Perusahaan Tambang Memprihatinkan. http://ekonomi.kompas.com/read/2016/10/27/152333226/kepatuhan.pajak. perusahaan.tambang.memprihatinkan. Diakses pada 9 September 2018. 
Sunardi dan Amin MN. 2012. Fraud Detection of Financial Statement by Supadmi, Ni Luh. 2009. Meningkatkan Kepatuhan Wajib Pajak Melalui Kualitas Pelayanan. Audi Jurnal Akuntansi dan Bisnis Vol. 4 No. 2, Denpasar: Indonesia.

Tahar, dan Rachman. 2014. Pengaruh Faktor Internal dan Faktor Eksternal Terhadap Kepatuhan Wajib Pajak. Jurnal Akuntansi dan Investasi, Vol. 15, No 1, Januari 2014, Hal : 57-67.Tahun 2016. Yogyakarta: Fakultas Ekonomi, Universitas Negeri Yogyakarta.

Umar, Husein. 2008. Metode Penelitian Untuk Skripsi dan Tesis Bisnis. PT. Rajagrafindo Persada, Jakarta: Indonesia. Using Fraud Diamond Perspective. International Journal of Development and Sustainability ISSN: 2186-8662 www.isdsnet.com/ijds. Volume 7 Number 3(2018): Pages 878-891 ISDS Article ID: IJDS18012004.

Widodo, Widi. 2010. Moralitas, Budaya dan Kepatuhan Pajak. Alfabeta, Bandung : Indonesia.

Www.pajak.go.id. Diakses pada 14 Oktober 2018.

Zeithaml, Valarie A., dkk. 2009. Delivering Quality Service. The Free Press, New York City: United States of America. 